\title{
Rehabilitation of Mining Sites: The Case of the Gora/Sabodala Gold Mine in Senegal Prospects for Sustainable Development of a Mine
}

\author{
Dieye Pathé ${ }^{*}$, Mall Ibrahim², Samb Mansour ${ }^{3}$, Ndong Robert ${ }^{4}$ \\ ${ }^{1}$ Institut Africain de Management, Dakar, Senegal \\ ${ }^{2}$ Amadou Makhtar Mbow University, Dakar, Senegal \\ ${ }^{3}$ Geology and Hydrogeology Applied to Mines and Major Civil Engineering Works, Dakar, Senegal \\ ${ }^{4}$ Environment Department at Sabodala Gold Operations, Dakar, Senegal \\ Email: * padieye2001@yahoo.fr
}

How to cite this paper: Pathé, D., Ibrahim, M., Mansour, S. and Robert, N. (2021) Rehabilitation of Mining Sites: The Case of the Gora/Sabodala Gold Mine in Senegal Prospects for Sustainable Development of a Mine. Journal of Environmental Protection, 12, 784807.

https://doi.org/10.4236/jep.2021.1210047

Received: August 17, 2021

Accepted: October 25, 2021

Published: October 28, 2021

Copyright $\odot 2021$ by author(s) and Scientific Research Publishing Inc. This work is licensed under the Creative Commons Attribution International License (CC BY 4.0).

http://creativecommons.org/licenses/by/4.0/ (c) (i) Open Access

\begin{abstract}
The southeastern part of Senegal, in West Africa, is home to the country's first major gold mine owned by Sabodala gold operations SGO, as subsidiary of Teranga Gold Corporation during the timeframe of this study. As part of its expansion, the company opened and operated the Gora satellite mine for 4 years' exploitation. At the end of the mine's life, the authorities decided to close the site. In this context, SGO in compliance with its legal, regulatory and normative obligations, has commissioned a study of rehabilitation activities for a better environmental and social management of the Gora gold mine. This study is a first in Senegal and presents the general framework for the rehabilitation of a gold mine which will allow scientists to have several research perspectives in this field. The methodological approach consisted of a participatory process of collecting field data and data from stakeholders directly involved in mine rehabilitation and closure; these data were analyzed and coupled with international best practices in rehabilitation, closure, and postmine management. Results of the selected options are based on known experiences from around the world, coupled with analysis of the SGO's field activities results and those obtained from the synthesis of the interview guides from the numerous consultations. This synthesis made possible to align them with international guidelines presented in this document. In this context, the aspects related to the open-pit mine equipment, processing facilities and related infrastructure were a particular interest to the various stakeholders. Thus, the following rehabilitation options were retained by the group constituted by the populations: 1) Backfilling pits, for cultivation practices and development of agribusiness and the establishment of grazing land for livestock; 2) Setting
\end{abstract}


up water storage basins for the sustainable development of certain activities around the mine and aquifer recharge while respecting the protection and safety standards of the basin in order to avoid the risks of accidents; 3) Returning certain facilities to the communities and the competent State services. These few measures will allow the indigenous populations affected by the mine to participate in the rehabilitation program by integrating all relevant ideas and discussions on the issues of rehabilitation as perceived by the actors involved in the study, as well as the implementation of the best international strategic orientations in this field for sustainable development. In addition, it will be necessary to set up an internal technical committee within the mining company to coordinate the rehabilitation and closure operations with the various departments, and an external technical committee composed of the relevant government departments, the local community, and civil society, among others, to examine and validate the closure options. A closure clearance should be issued to operators who have responsibly closed their mines.

\section{Keywords}

Rehabilitation, Mine Closure, Gora, Sabodala, Environment, Sustainable Development

\section{Introduction}

The exploitation of non-renewable mineral resources in a sustainable development perspective can be like squaring the circle. However, use of minerals and metals is an essential condition for of human progress and the development of civilizations, from flint tools to the most sophisticated electronic devices. Mineral resources are essentially non-renewable, as the constitution of deposits occurs over thousands or millions of years, obviously much longer than the time it takes for humans to extract the ore from a deposit [1]. Today, many countries in the world such as France (iron mines in Lorraine, gold mines in Salsigne) and the United States (uranium mines in Southeast Dakota), which were involved in the development and exploitation of mineral resources in the 20th century, have been confronted with a very complex problem rehabilitation of mining sites during and at the end of their exploitation linked to pollution of surface and groundwater (examples: cases of the Salsigne gold mine in France, the Kettara pyrrhotite mine in Morocco), of agricultural land, of air and to a very advanced degradation of biophysical environment in a general way making these zones unlivable in the long term [2]. According to the World Bank, more than 3.5 billion people live in countries rich in hydrocarbons and mineral resources. However, these deposits are too often a source of conflict rather than an opportunity for development. Many of the resource-rich countries are also victims of poor governance that leads to poverty, corruption and conflicts. It is important to understand that the interest and willingness to consider the environmental dimension of mining activities have evolved progressively before arriving at a require- 
ment for environmental rehabilitation in a chronology that can be summarized as follows [3]:

1) Lack of interest in the environment: exploitation of resources and mine closure without any environmental and social management measures;

2) The emergence of a new awareness with the protest movements in indigenous populations, resulting in the implementation of small-scale greening programs in the front of certain large companies;

3) Involvement of the States through legislative and regulatory reforms which, despite the need to develop their mineral resources, make Environmental and Social Impact Assessments (ESIA) mandatory, including the requirement of a rehabilitation plan;

4) The advent of global changes and the birth of strategic environmentalism, which has three components: performance standards, environmental management systems and international standards.

This study is an intervention work articulated to the service package for the gold mining Company Sabodala Gold Operations. The objective of this work is focused on the study of rehabilitation activities carried out by the company SGO for a better environmental and social management of the gold mine. The methodological approach consisted of a participatory approach to collect field data and data from stakeholders directly involved in the rehabilitation and closure of the mines. These data were analyzed and coupled with international best practices in post-mining management. This was done by elimination based on technology or practice recognized by experts in the field [4]. This approach allowed us to make a better choice on rehabilitation options that would allow the company to proceed to a mine closure while respecting the country's regulations and taking into account the concerns of stakeholders (indigenous populations, gold miners, government technical services, etc.).

\section{Overview of Environmental Issues and Mine Rehabilitation}

Sustainable development has become a major issue that any mining company must take into account with the utmost rigor. CSR policies and their inclusion in studies and projects are increasingly being emphasized around the world, as evidenced by the work of [5]-[10].

Reclamation includes the design and construction of landforms, as well as the establishment of sustainable ecosystems or alternative vegetation, depending on the intended use of the land after operations are complete.

Mine site reclamation should seek to fulfill three key objectives:

1) The long-term sustainability and stability of the site's landforms, soils, and hydrology;

2) Partial or full restoration of the ecosystem's ability to provide habitat for biota and services to people [11];

3) Prevention of pollution in the vicinity of the site.

Several terms have been used to describe the repair of land disturbed by min- 
ing or other land use activities, including: rehabilitation, reclamation, reconstruction, repair, restoration, and revegetation. In order to be consistent with the National Standards for the Practice of Ecological Restoration in Australia [12], the two main terms used in this manual are rehabilitation and restoration.

To address these very difficult issues, this study emphasizes on consulting stakeholders in order to identify the best sustainable solutions for the successful rehabilitation of a gold mine in Senegal. In the context of rehabilitation, the Society for Ecological Restoration [12] recommends the use of nine ecosystem attributes to measure the success of rehabilitation operations ("rehabilitation" in the context of mine sites):

- the diversity of ecosystem structures similar to that of reference sites (initial or baseline condition);

- the presence of native species;

- the presence of functional groups necessary for long-term stability;

- the ability of the physical environment to support breeding populations;

- normal functioning;

- integration into the landscape;

- elimination of potential hazards;

- resilience to natural disturbances;

- autonomy.

According to [13], few restoration studies had sufficient financial resources to control all these factors. In their review of 68 studies, they found that most of the measures evaluated could be categorized into three types: diversity, vegetation structure, and ecological process attributes. Of these three categories, they also found that ecological processes are rarely measured, given their slower recovery compared to diversity or vegetation structure.

The segmented character of mine site rehabilitation must also be considered when addressing the use of ecological processes and ecosystem services, as well as the attributes of the criteria used to monitor success. In some circumstances, it may not be possible to use ecosystem service attributes to monitor reclamation success on small sites or on sites where reclamation is light.

In Africa, several mines have been exploited and closed without any form of reclamation [14] [15]; in Morocco, 200 abandoned mining sites without any environmental management measures have been listed [16]; these often-polluted sites create significant inconvenience for local residents. In Senegal, the largest phosphate mine in the country, the Taiba mine, has closed several of its mining sites, leaving behind a degraded environment [17]. The study conducted by the African Union (AU) as part of the "African Mining Vision" adopted by the Heads of State and Governments revealed that the environment is very degraded and the populations are very affected by mining operations. With the directives of donors, notably those of the World Bank on environmental protection and the standards of the International Finance Corporation [18], mining companies are increasingly required to restore the environment as part of their activities. In 
addition, there are exogenous factors that are very difficult to take into account.

In Niger, the planned closure of the Akouta mine (Cominak) in the first quarter of 2021 will have very harmful consequences for the country, leading to the loss of 600 employees. In South Africa, according to the APEC Mining Industry Task Force (February 2021) 6000 mines have been closed; indeed, the decline in deposits considers the South African mining sector as a Dinosaur on the verge of extinction. The first consequence would be the difficulty of sustainable management of the thousands of mining sites with job losses, the difficulty of reconverting mine workers, the risks of pollution and land degradation, acid mine drainage after passive closure without follow-up, security risks, loss of biodiversity, the difficulty of governments resilience that depends mainly on taxes from these mining operations. These are all consequences that undermine sustainable development. Thus, in Africa in general, an acceleration of mine closures is noted with very damaging consequences; These early closures are linked to several factors, including the decline in mining deposits, the advent of rapid extraction and exploitation technologies that considerably shorten the life of projects, and errors in the technical, economic, social and financial studies of new discoveries, the difficulty of exploiting high-grade ores to extend the life of a mine, most often located in sites classified as cultural heritage and with a high biodiversity potential constituted by protected species, and finally an unfavorable global economic context that is sometimes unpredictable (covid19 context in 2020 as an example). These different factors lead to an unscheduled and very rapid closure of several giants of the mining sector, causing enormous difficulties for a rehabilitation that respects national and international standards.

In Senegal, there are 97 projects in the Ministry of Environment and Sustainable Development database that have undergone environmental procedures in the extractive sector divided into 12 categories; these include gold projects, sand mining, manganese, basalt, sandstone, lime phosphate, limestone/cement, zircon, gravel and concrete, dune mining, clay, laterite, and coal/power plants. In the mining sector, 20 environmental studies were underway in 2018 in Senegal, and each of them mandatorily incorporated a mine rehabilitation and closure plan [18]. The Ministry of the Environment and Sustainable Development through its Technical Direction in charge of the Environment and Classified Establishments (DEEC) [19] is responsible for monitoring this issue in the context of the application of rehabilitation plans made mandatory by the mining code and environmental assessments prior to the delivery of any operating permit.

However, the information on rehabilitation is very scarce and often not available. Mostly, the post-mining phase is ignored in the management of mining operations. It is becoming increasingly urgent to anticipate on the problematic of mine site rehabilitation in order to prevent environmental and social issues associated with the end-of-life mining, which would make the areas of mining operations unlivable. The consequence of these failures has been noted in several localities in the country; in the Thiès region, the Senegalese department of the environment noted in 2020, more than a hundred pits have been exploited and 
abandoned without any environmental management measures, including site rehabilitation. Environmental legislation (Law 2001-01 of January 15, 2001 on the environmental code) does not foresee any provision for the rehabilitation of mining sites, which makes sustainable development of the mining sector very difficult. The new Mining Code (Law 2016-32 of November 8, 2016) takes very little consideration of the very actual issue of rehabilitation. Decrees instituting a rehabilitation fund were formulated in 2009, but because they predate the 2016 law on the new Mining Code, several inconsistencies are noted and stakeholders do not reach consensus on the financial terms associated with the closure and rehabilitation of mining sites.

Sustainable development in the extractive industry has been sufficiently studied, documented and shared by [20]-[30]; the urgency in the sector today lies in the systematic application of the recommendations resulting from these studies.

\section{Presentation of the Study Area}

In the southeastern of Senegal, several gold deposits and pits (Figure 1) are being exploited by Sabodala Gold Operation which represents the main gold mining company. It has had to carry out several environmental impact studies as well as rehabilitation and closure plans. Strict inspections and monitoring by the government's environmental department have resulted in the company's compliance with all legal and regulatory requirements. Sabodala Gold Operations has even gone beyond its obligations under the country's regulations by implementing very stringent environmental and safety procedures, which earned them the excellent standard of more than "10 million hours without a lost time incident" in 2016. In the southeastern of Senegal, effective implementation of rehabilitation plans remains very difficult due to environmental, social, and community

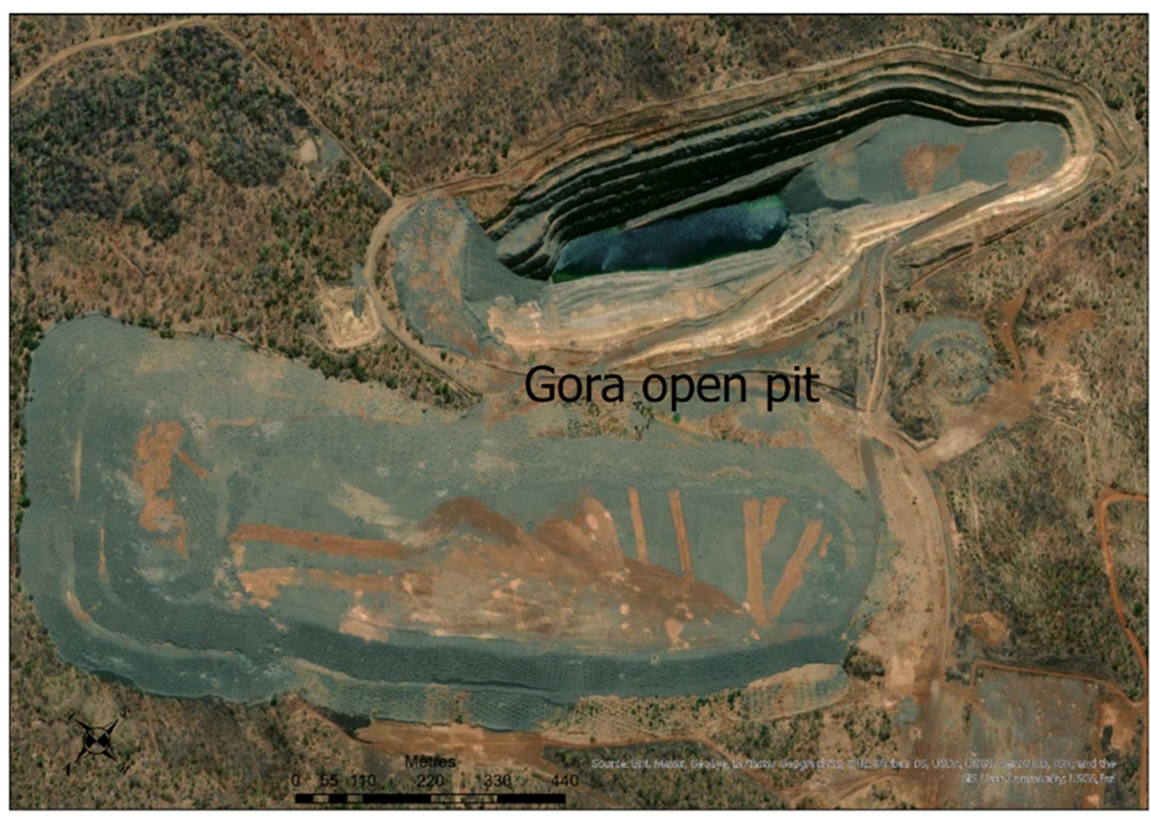

Figure 1. Gora Open pit. 
problems. The planning of mining operations is difficult to assimilate with rehabilitation and closure activities. Closed sites undergo profound environmental changes related to the high risk of pollution from hazardous industrial waste. Mining facilities such as offices as well as goods and services which are highly coveted by the state on the one hand and by the populations who want to reuse them on the other. However, the new gold mining projects, notably Petewol Mining Company, have validated rehabilitation plans. Nevertheless, their implementation does not take into account prior rehabilitation tests before the execution of the plans. The Sgo Company has launched a process of experimental rehabilitation trials in the form of randomized blocks. This has given very positive results both for the technical and financial planning of the closure of its mines. Scientific work carried out on TSF for the valuation of sabodala mining residues [31], has revealed gold mining industry for achieving sustainable development.

\section{Location of Gora Mining Site}

The study area is located in the eastern-most part of Senegal between longitudes $11^{\circ} 56^{\prime} 47^{\prime \prime} \mathrm{W}$ and $11^{\circ} 55^{\prime} 13^{\prime \prime} \mathrm{W}$ and latitudes $13^{\circ} 17^{\prime} 22^{\prime \prime} \mathrm{N}$ and $13^{\circ} 18^{\prime} 46^{\prime \prime} \mathrm{N}$. The area is part of the eastern Senegalese basement region (Figure 2) marked by the

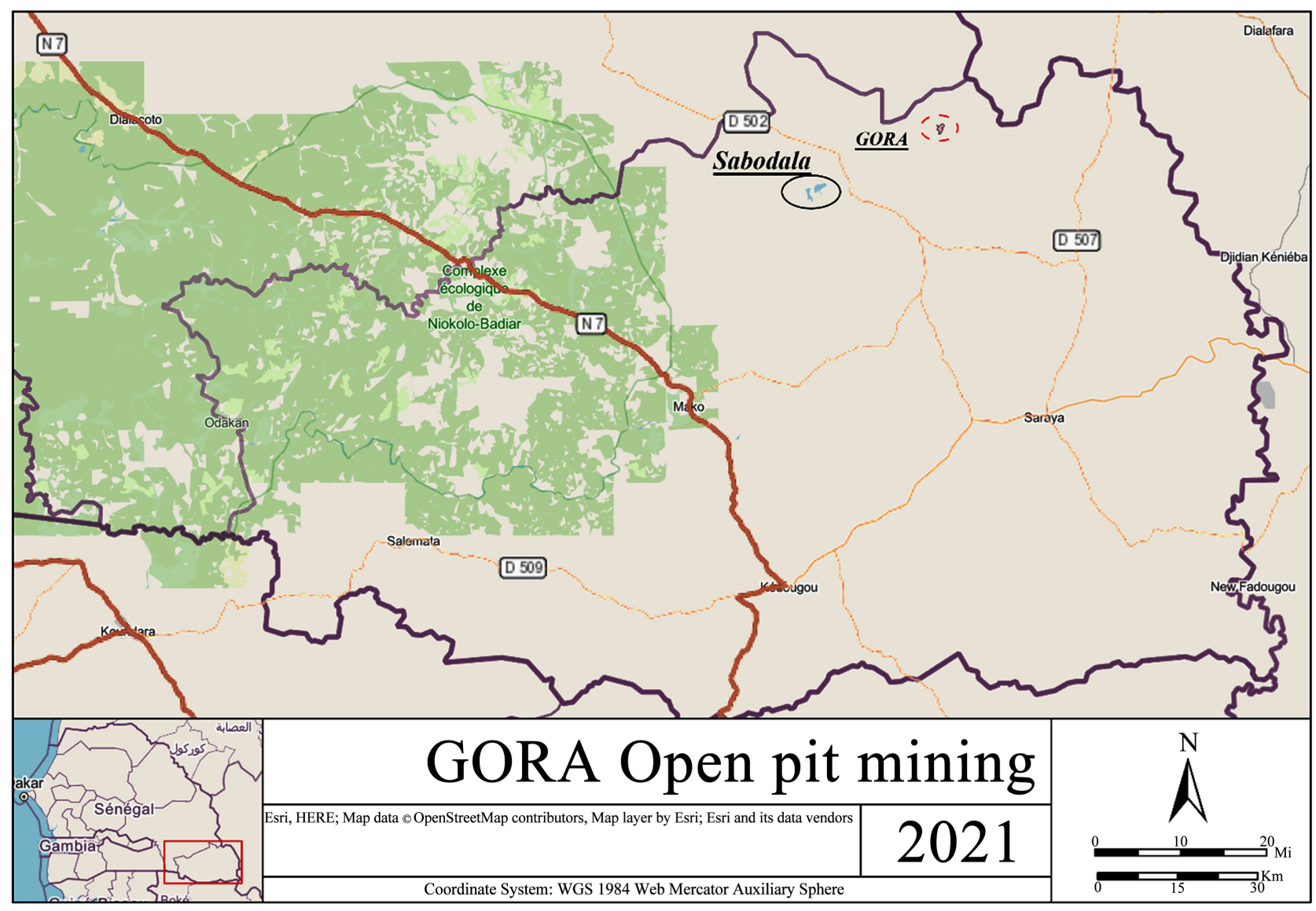

Figure 2. Location of the Gora mine. 
predominance of Paleoproterozoic (Birimian) age terrain, making this part of Senegal a high potential gold mining area. The area is part of the Sudano-Guinean climatic context, characterized by three seasons: rainy, cold dry and hot dry seasons. Temperatures at the project site hover around $25^{\circ} \mathrm{C}$ throughout the year and exceed $30^{\circ} \mathrm{C}$ during the hot dry season, with daytime temperatures generally above $40^{\circ} \mathrm{C}$. The maximum temperature recorded at SABODALA in 2011 was $42.8^{\circ} \mathrm{C}$ and has not changed until 2018 . Humidity at the project site has high seasonal variability, from less than $20 \%$ in the dry season to $80 \%$ at the end of the wet season. The site experiences a rainfall deficit with an average annual precipitation of $908 \mathrm{~mm}$ and an open water evaporation rate of $2353 \mathrm{~mm}$ per year [32]. From a vegetation standpoint, the natural cover is a mixture of forest and grassland. Lands are used primarily for agriculture, artisanal gold mining, livestock husbandry, and grazing [32]. The soils in the project site are primarily sandy, clay, and lateritic soils. The area hosts a very high biodiversity and is located at the border of two ecoregions: Sudanese savanna and the Guinean: forest-savanna mosaic. The soils of the project site are essentially sandy, clayey and lateritic.

In the area, the relief is relatively flat, with a few hills which altitudes ranging from 150 to 170 meters. However, to the east of the study area, towards the Falémé River, there are large valleys forming lowlands with altitudes of around 90 and 69 meters. Between these lowlands and the Gora project area are located large plateaus characterized by tabular relief with altitudes ranging from 100 to 140 meters (Figure 3).

The Gora site is located on the crest line separating two watersheds, and there are no perennial water sources on site, but the drainage network which shows a drainage axis that may be active in rainy season corresponding of winter months. This no perenial course represents a tributary of a small river that is itself a tributary of the Falémé. This means that at the Gora site, surface water runoff only occurs during and after an effective rainfall event. To the east of Gora, the water is drained into a sub-basin of the Falémé River, while to the west it is drained into a sub-basin of the Gambia River (Figure 4).

\section{Methods}

Successful closure of a gold mine requires involvement of all key stakeholders and rigorous environmental data collection. Due to the absence of a legislated approach to closing the mine, the SGO company in conjuction with the regional environment division of kedougou took the leadership to responsibly close the mine. The activities carried out have been detailed in this report. Interviews were conducted at three levels (national, regional, and local) (Figure 5). In this study, we collected data from institutional actors through interview guides using a semi-directive survey method. All information collected was sufficiently triangulated to obtain the best results, as this is the first gold mine in Senegal that is being closed. At the regional level, a regional technical committee was estab- 
lished by the Governor of the Kédougou region. Throughout the closure of the Gora mine, meetings of the technical committee were held every three months, which helped to stabilize all field activities and, their reporting to higher authorities. All key decisions were stabilized and validated by consensus. Concerning local actors, consultations were carried out through local workshops organized at the local level. Focus groups are also be used to collect the necessary data and information. All closure options were discussed (Table 1) in the local language and, whenever necessary, people using the closed sites were given the opportunity to visit areas where similar activities were taking place (visit to the pilot mercury-free gold processing unit, field visit with the land registry to map sites for future use by the population, etc.). All of the mine rehabilitation and closure activities presented in the results were obtained through these methodological approaches. Environmental data were collected during the visits in the mine site, which allowed to map the site before and after mining in order to get a clear idea of the initial state of the environment and to provide corrections to the modifications caused by the mining activities.

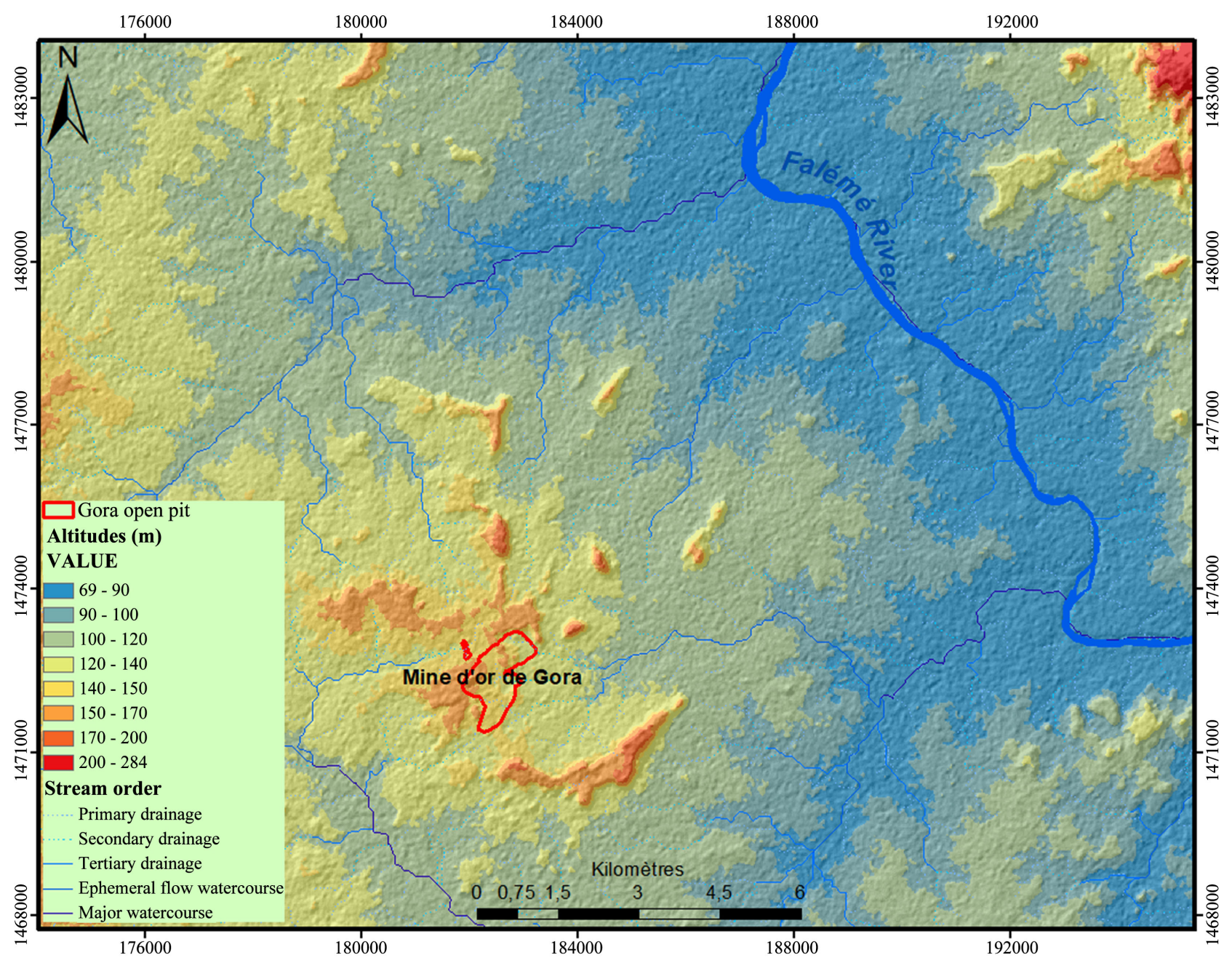

Figure 3. Distribution of altitudes at the Gora site (Alos PAlsar). 


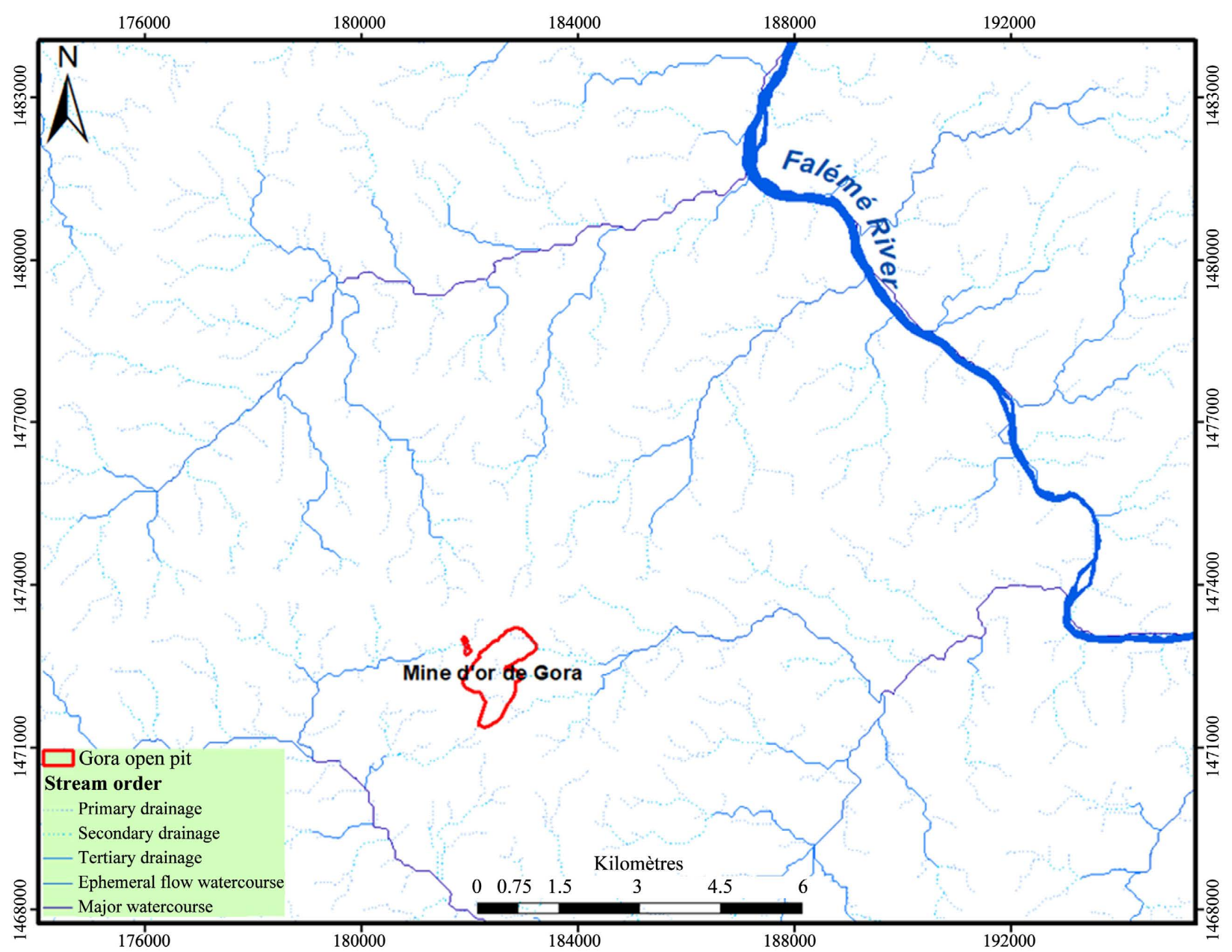

Figure 4. Distribution of the drainage network in the Gora Site.

Table 1. Closure options for the gora mine.

\begin{tabular}{ccc}
\hline Closure Strategy & Mining Pit & Future Use In Post-Closure Phase \\
\hline $\begin{array}{c}\text { Slope stabilization } \\
\text { Securing and restricting access }\end{array}$ & Tailings Piles & Artificial pond \\
\hline $\begin{array}{c}\text { Slope stabilization } \\
\text { Spreading organic soil }\end{array}$ & Grazing \\
\hline $\begin{array}{c}\text { Aménagement de demi-lune anti-érosive } \\
\text { Low ore grade (green stockpile) }\end{array}$ & Progressive nature recovery \\
\hline \multicolumn{2}{c}{ Installations And Facilities } \\
\hline
\end{tabular}

Mining workshop (light vehicles, civil fleet, heavy equipment workshop ...)

Office blocks

Geology Hangars and Office block.

Oil deposits

Rest areas

Post-closure monitoring

Haul road
Dismantling, demobilization, decontamination, decommissioning, ecological cleaning, scarification of sites and assignment or provision of other services after validation by the competent structures in order to minimize institutional and organizational responsibilities (State, Company ...).
Responsibility of the state's technical services Ceded to local community 
Focus group with local stakeholders and data collection for mapping.

Figure 5. Outline of the methodological approach to collecting data from targets in the context of the of Gora mine closure.

\section{The Role of Stakeholders}

Early and effective engagement with stakeholders is one of the critical aspects of managing the rehabilitation operations for sustainable development, as they are intense and changes can occur at any time. In this context, stakeholders are all people who have a justified interest or specific involvement in the project and its impacts (positive and negative) on post-mining land use. Stakeholder commitment faced to the rehabilitation objectives is one of the fundamental aspects of setting the objectives. It is very important to align their expectations as closely as possible with the realities of the rehabilitation program [33].

The objective was to assess their knowledge level in rehabilitation issue in order to identify capacity building actions and to reach a consensus on the future uses of the mining project components by involving all stakeholders in the choice of all closure options. The structures involved in this work are the departments in charge of local territorial development, the departments in charge of land management, the departments in charge of natural resource and environmental management, as well as any stakeholder directly or indirectly involved.

The following aspects were the focus of the discussions:

- Sharing the closure decision and key concepts;

- The presence of a low-grade ore available on the site and highly coveted by local actors (illegal gold miners, local communities);

- The site's safety and geotechnical instability issues that the company has tried to address in the context of the mine's rehabilitation;

- Implementation of preliminary rehabilitation activities based on the rehabilitation plan validated as part of the Gora Mine Environmental Impact Study. The rehabilitation activities are available in the environmental impact study [32];

- The future destination of the site, particularly the extraction open pit (see Photo 3), which the company has studied the feasibility of fencing off; 
- The installation of a gendarmerie unit on the site after the mine closes to prevent intrusions into the mine and to reinforce the security on site after closure;

- The grouping villagers associations living near the Gora mine into an economic interest group (EIG) in order to enable them to exploiting the lowgrade ore and the materials likely to be used in the construction of infrastructure, roads and hydroelectric dams in a sustainable and consensual manner;

- Visit village group associations working in gold processing units without harmful products in order to exploit low-grade ore;

- Work with the regional technical committee for the closure of the Gora mine, established by order of the governor of the Kédougou mining region, to identify future and long-term uses for the site;

- Validate the closure options and recruit a consultant to evaluate or audit the rehabilitation in order to help government to issue a closure permit. (Photo 1)

Following the analysis of the results of the intervention, we identify several weaknesses that constitute a barrier to the rehabilitation and closure of mines in Senegal and in the Southeast region in particular:

- The expectations of the mining company are not well known and not adaptable by the future recipients of these mining sites;

- The institutional actors and local communities in charge of decision-making are not aware of the existence of plans for the rehabilitation and closure of mines validated in the context of environmental impact studies;

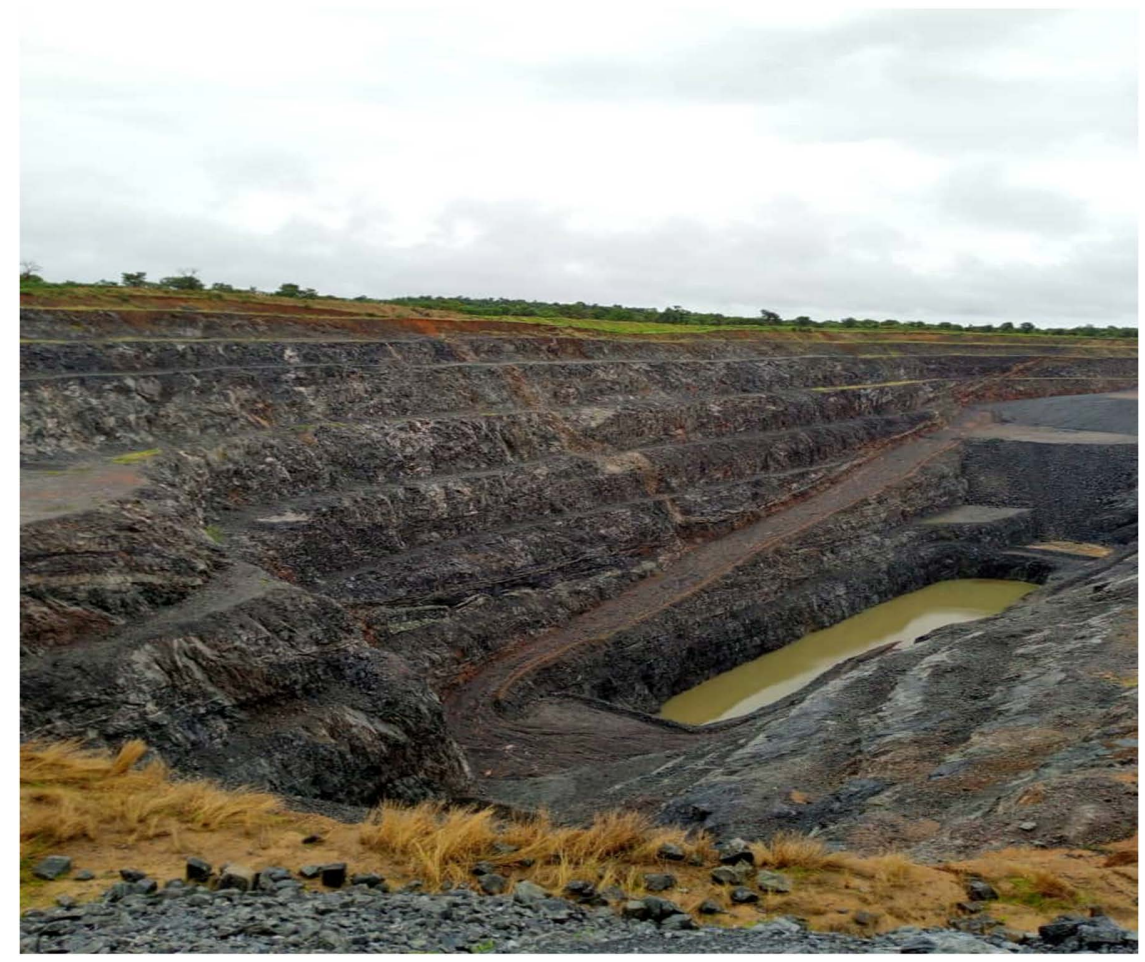

Photo 1. Gora open pit mine at the end of operations in rehabilitation phase (Diéye Pathé, 2014). 
- No institutional actor involved in the rehabilitation of gold mines has visited a closed gold mine; therefore, most actors are not aware of the issues specifically related to the closure of a gold mine;

- Most of the complex facilities such as TSFs (tailings management facilities) are not known by the different actors, even though these are the facilities that can pose the most problems during the post-mine period for indigenous populations;

- Very difficult consensus in the guarantee of closure of mining sites;

- The populations are not aware of the risks and dangers of a closed mine, which leads them to demand the use and reuse of the gold ore residues left by the mining companies;

- Beyond the gold projects, the rehabilitation of basalt and laterite quarries in the open air has failed in the medium term, with fatal drownings of children and frequent landslides linked to the lack of geotechnical stabilization of these sites (statistical data available from fire department groups);

- The relationship between the mining companies and the local communities is very fragile;

- The presence of residual gold and other low-grade precious minerals in closed mines generally creates a dangerous multi-actor attraction that is extremely difficult to manage by the structures responsible for controlling access to closed mining sites;

- The strong long-term dependence of populations on the mining company makes very difficult the securization of gold sites at the end of exploitation.

\section{Results of Field Surveys (Primary Data)}

The results presented are drawn from the bibliography, coupled with the analysis of field activities and those presented in the summary tables of the guidelines resulting from the consultations. This synthesis allowed us to align them with international guidelines, as it is accepted internationally according to the work of [4] that the aspects recorded in Table 2 allow for easy identification of elements of mine closure and therefore, in the case of this study, for relevant discussion of rehabilitation issues as perceived by the actors involved in the study, as well as the best international strategic orientations in this area.

The result is integrated in this table which takes into account the rehabilitation options for each facility and the future use derived from the analysis of the semi-directive consultation data.

\section{International Closure Planning}

It is internationally accepted according to the work of [4] that the following aspects should be taken into account when planning the closure of mining sites depending on the equipment on site. We presented in Table 3 and Table 4 the model we used for this study.

Content of the closure decision 
Table 2. Summary of proposed consensus options for rehabilitation and closure of the gora/sabodala gold mine.

\begin{tabular}{|c|c|c|}
\hline Facilities & $\begin{array}{l}\text { Issues to be taken into account for a good rehabilitation } \\
\text { and closure }\end{array}$ & $\begin{array}{l}\text { Elements of rehabilitation desired by the consulted } \\
\text { stakeholders }\end{array}$ \\
\hline $\begin{array}{l}\text { Underground } \\
\text { mines }\end{array}$ & $\begin{array}{l}\text { Backfilling of pits, slopes and ventilation shafts; effects of } \\
\text { contaminated water from backfill, drainage of overburden }\end{array}$ & $\begin{array}{l}\text { Not applicable: } \\
\text { There are no underground mines in Senegal }\end{array}$ \\
\hline Open-pit mines & $\begin{array}{l}\text { Slope stability; ground and surface water management; security } \\
\text { and access interdiction; effects of drainage to wells; removal of } \\
\text { disposal routes }\end{array}$ & $\begin{array}{l}\text { Pit Fills, Farming Practices, Agribusiness } \\
\text { Cattle runs, Water retention ponds. Prohibition of access to } \\
\text { population }\end{array}$ \\
\hline $\begin{array}{l}\text { Treatment } \\
\text { facilities }\end{array}$ & $\begin{array}{l}\text { Removal of buildings and foundations; removal of fixed and } \\
\text { mobile infrastructure; cleanup of workshops, fuel and reagent } \\
\text { storage areas; waste disposal; site reprofiling and revegetation. }\end{array}$ & Hand over facilities to the relevant government departments \\
\hline
\end{tabular}

Table 3. Mining facilities to be considered in closure programs.

\begin{tabular}{|c|c|}
\hline Facilities & Aspects to be taken into account \\
\hline Underground mines & $\begin{array}{l}\text { Backfilling of pits, slopes and ventilation shafts; effects of contaminated water from backfill, drainage } \\
\text { of overburden }\end{array}$ \\
\hline Open-pit mines & $\begin{array}{l}\text { Slope stability; groundwater and surface water management; security and access prohibition; drainage } \\
\text { effects towards wells; removal of disposal roads. }\end{array}$ \\
\hline Treatment facilities & $\begin{array}{l}\text { Removal of buildings and foundations; removal of fixed and mobile infrastructure; cleanup of facilities, } \\
\text { fuel and reagent storage areas; waste disposal; site reprofiling and revegetation. }\end{array}$ \\
\hline Waste rock and the topsoil piles & Reinforcement of embankments; leaching effects on runoff; dust; visual impact. \\
\hline Management of the decantation ponds & $\begin{array}{l}\text { Dam stability; geochemical changes in mine wastes; percolation effects through dams and bottoms of } \\
\text { ponds; surface water and effluent management; dust generation from perimeters; access and security. }\end{array}$ \\
\hline Hydraulic facilities & $\begin{array}{l}\text { Stability of dams, reservoirs, decantation basins, pipes, channels, outlets; sludge disposal from } \\
\text { treatment plants; surface drainage and elimination of drainage effluent. }\end{array}$ \\
\hline Facilities & $\begin{array}{l}\text { Removal of electrical and water supply facilities; remodeling of access roads and evacuation; reuse of } \\
\text { supply yards and loading docks. }\end{array}$ \\
\hline Exploration areas & Rehabilitation of drilling areas and access roads. \\
\hline
\end{tabular}

The closure decision should include:

- The initial closure study, prepared during the approval phase of a new operation (or during operation) and designed to establish how closure could be achieved;

- Progressive site rehabilitation must be undertaken the earlier as possible;

- An interim closure plan, prepared taking into account the progress of the operation or changes in regulations;

- The final closure plan, which must be completed before the final closure date. Closure management includes the following elements:

- MINE closure and concession termination, cleanup, dismantling and removal of mining facilities;

- Active remediation: treatment and rehabilitation of the site;

- Passive remediation: monitoring to ensure the success of active remediation operations;

- Formal closure: the regulatory authorities approve the successful completion of closure operations, finalized in an abandonment report;

- The release of the site: the beneficiaries give up their interest in the mine site. 
Impacts on natural resources

Table 4. Sensitive Natural Resources.

\begin{tabular}{ll}
\hline Natural Resources & Potential Impacts \\
\hline Surface water & Quality and quantity effects of drainage water \\
Groundwater & $\begin{array}{l}\text { Effects of seepage on groundwater quality } \\
\text { Habitats-biotopes }\end{array}$ \\
$\begin{array}{l}\text { Effects on aquatic biotopes and neighboring terrestrial habitats } \\
\text { Flora and fauna }\end{array}$ & $\begin{array}{l}\text { Specific effects on certain species; deterioration of areas providing food and } \\
\text { feeding and breeding areas; migration routes }\end{array}$ \\
Land use Induced & changes in agriculture and forest management \\
\hline
\end{tabular}

\section{Purpose}

- To ensure a productive and sustainable future use of the site that is acceptable to both concessionaires and regulators;

- Protect public health and safety;

- To reduce environmental damage;

- Maintain the legacy of the site;

- Minimize negative socio-economic impacts.

Benefits of progressive reclamation

- Closure measures are integrated into mining operations;

- Implementation and monitoring are integrated into ongoing environmental management;

- Proven rehabilitation techniques can be incorporated into the final closure project;

- Costs are extended over a longer period of time and can be covered by revenues from operations;

- Adverse environmental effects are minimized; and finally;

- The phase leading up to final closure is reduced.

\section{Results (Secondary Data)}

\section{Some Examples of Rehabilitation and Closure}

This closure planning was translated into concrete actions in the field. To better achieve this mission, SGO conducted tests with the National Institute of Pedology (INP) and a followed up quarterly by the Regional Division of Environment and Classified Establishments (DREEC) was made in order to optimize the rehabilitation strategies (Table 5).

Pollution in closed mines leaves a very negative global image of the industry and compromises the achievement of sustainable development in the mining sector. Analyzing the consequences of pollution in the mining sector on a global scale as described by the work of [34]-[38] and respecting its environmental and societal commitments between the state and communities, the company Sabodala has carried out a rehabilitation program through revegetation trials under randomized blocks (see Photo 2); this program has made it possible to reduce pollution considerably. Other scientific publications will present the results in detail. 
Table 5. Example of teranga gold corporation in Senegal.

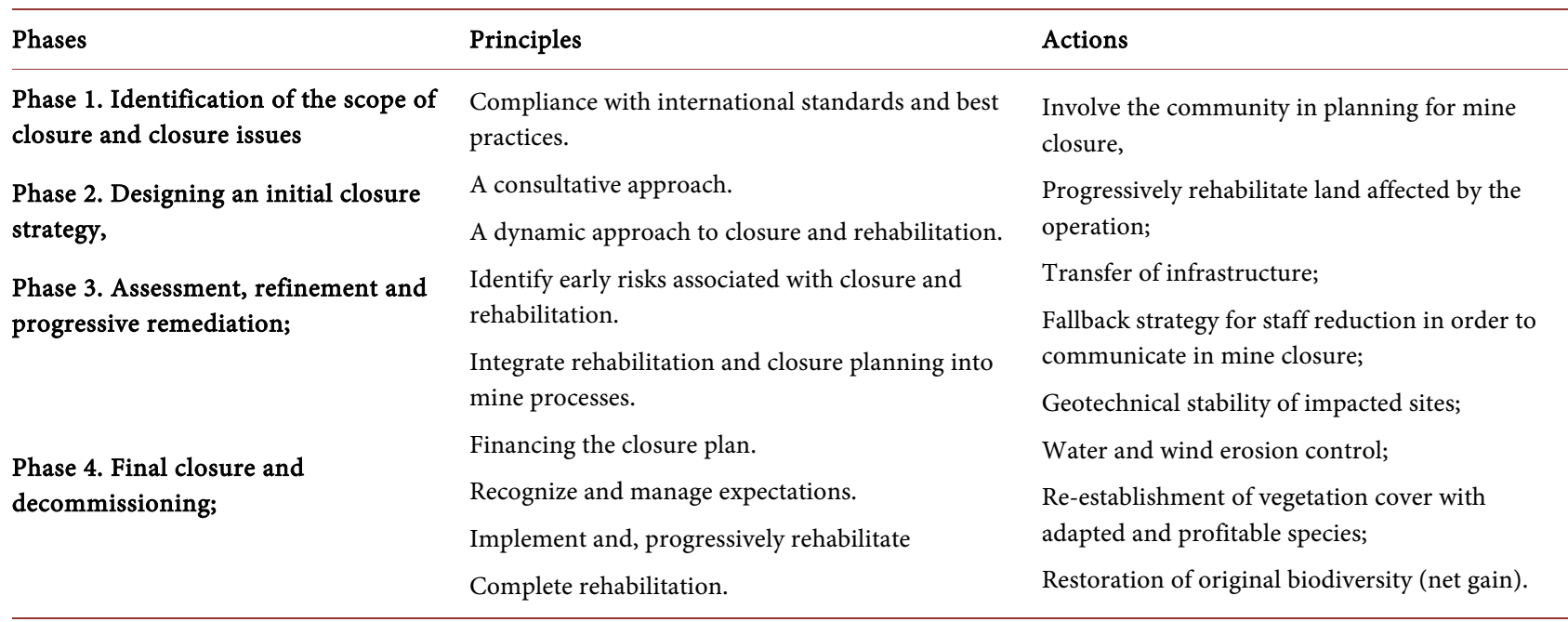

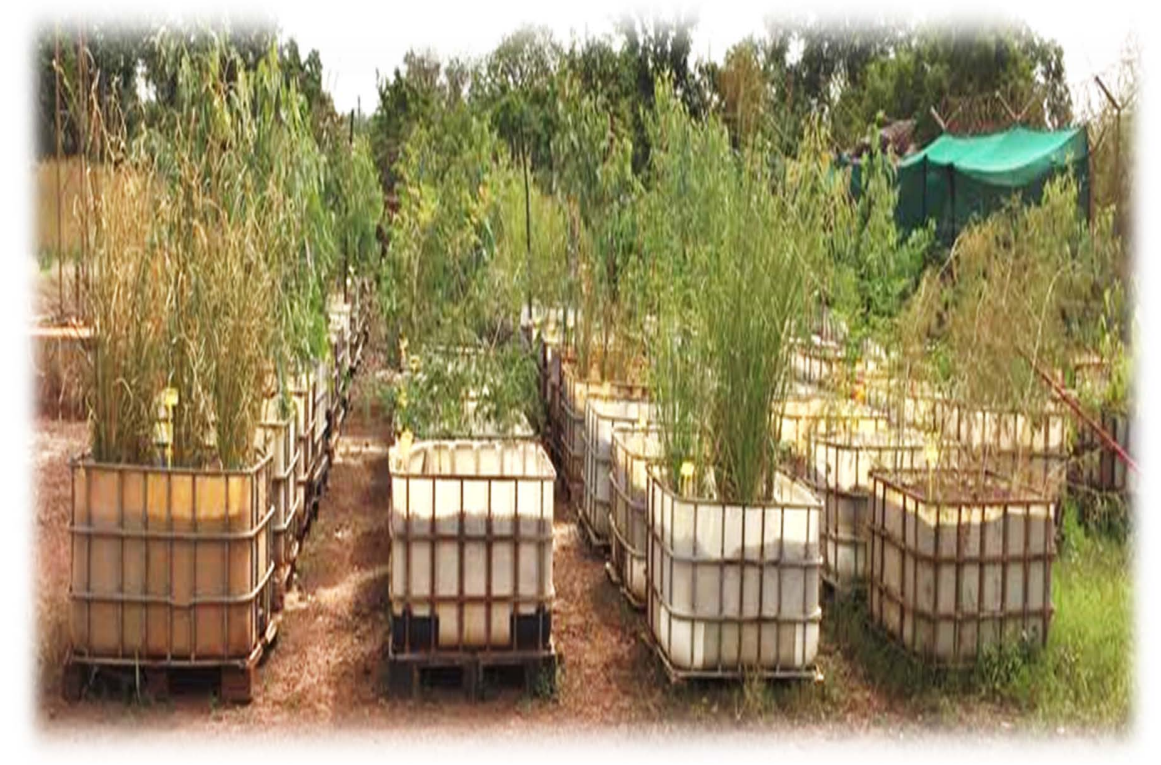

Photo 2. Blocks test containing soil samples and plant species in different environments types (photo credits, environment department of Sabodala gold operation).

Indeed, SABODALA undertook a revegetation using Eucalyptus camaldulensis on one site and natural regeneration on another site. The revegetation experiments using Eucalyptus camaldulensis gave acceptable results both in terms of species abundance and cover and in terms of biological diversity. However, recolonization by a grassy stand is more satisfactory in the natural regeneration zone than in the revegetation zone [39]. This recolonization by a grassy pioneer stand that paves the way for primary succession is an indicator of a positive evolution of the ecosystem. In this context, revegetation using Eucalyptus camaldulensis has weaknesses that means, it should not be used systematically. Indeed, the introduction of Eucalyptus camaldulensis, which is an exotic species, contributes to the modification not only of the local landscape, but also of the 
ecosystem. In addition, there is the risk of pathologies or parasitic attacks. In terms of ecological goods, Eucalyptus camaldulensis, even if it can be a palliative solution to the pressure on ligneous species, especially protected ones, is still very little known by the local population. In this respect, no cultural or cultic practice associated with Eucalyptus camaldulensis in the area has been identified. This raises the question of whether the local population was properly involved in the selection of Eucalyptus camaldulensis species.

Based on these observations and remarks, SGO has increased its plants production for the year 2018 and 2019 with seedlings of which the largest number are the fast-growing species and species of the Moraceae family that are best adapted on these difficult to handle soil types. The following species were used; they are Leucena leucocephala, Anacardium occidentale, Acacia melifera, Acacia raddiana, Acacia polyacantha, Prosopis juliflora, moringa oleifera. All these species are local and well adapted to the environment (Photo 3, Table 6).

\section{Example of the gold mine of Salsigne}

In this site, apart from gold, there was an exploitation of arsenic, a very toxic substance which pollutes soils and waters threatening their later use. The industrial contamination level of the building prevented any reoccupation of the site. Faced this complex problem, the company called on specialized engineering firms to carry out a global diagnosis. The result was the development of a financially feasible intervention scenario, namely:

- The removal of toxic waste and its evacuation to specific treatment sites;

- The demolition of all constructions;

- The storage on site in a confining area of the demolition wastes and the excavated polluted deposits with the control of the underground water (use of a geomembrane to prevent the infiltration of rainwaters in the waste waters);

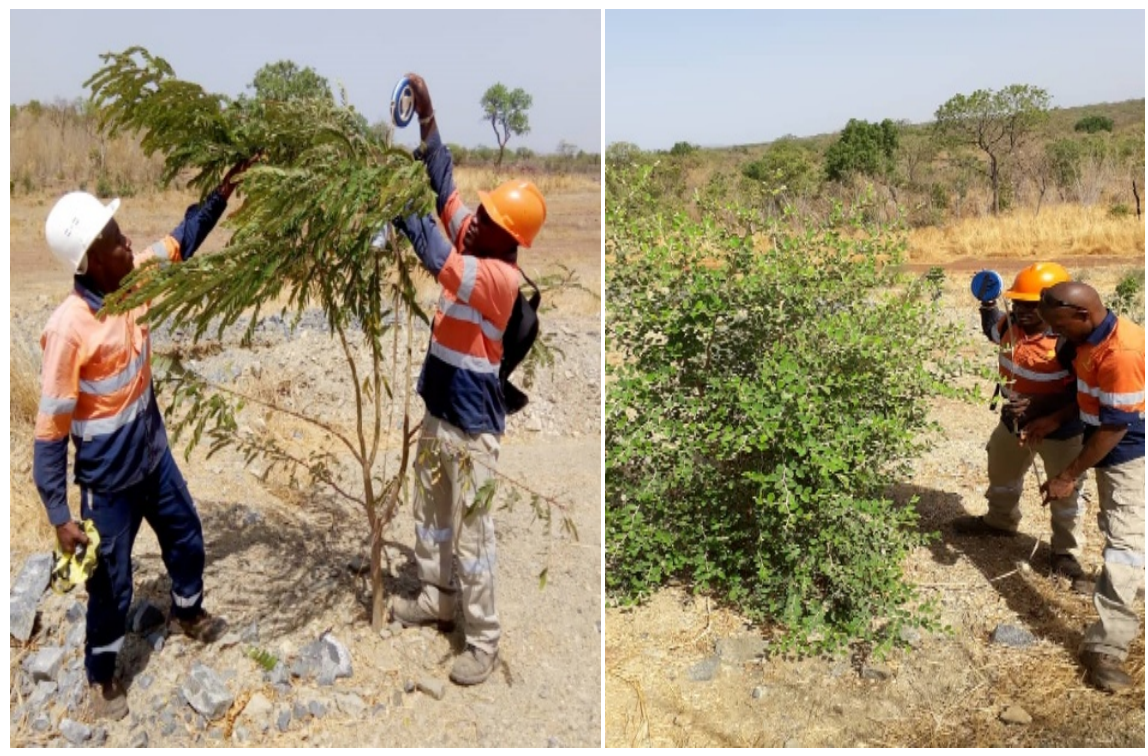

Photo 3. Monitoring of rehabilitation tests (source: Environmental Department of Sabodala Gold Operation). 
Table 6. Population expectations from public consultations (local consultation report).

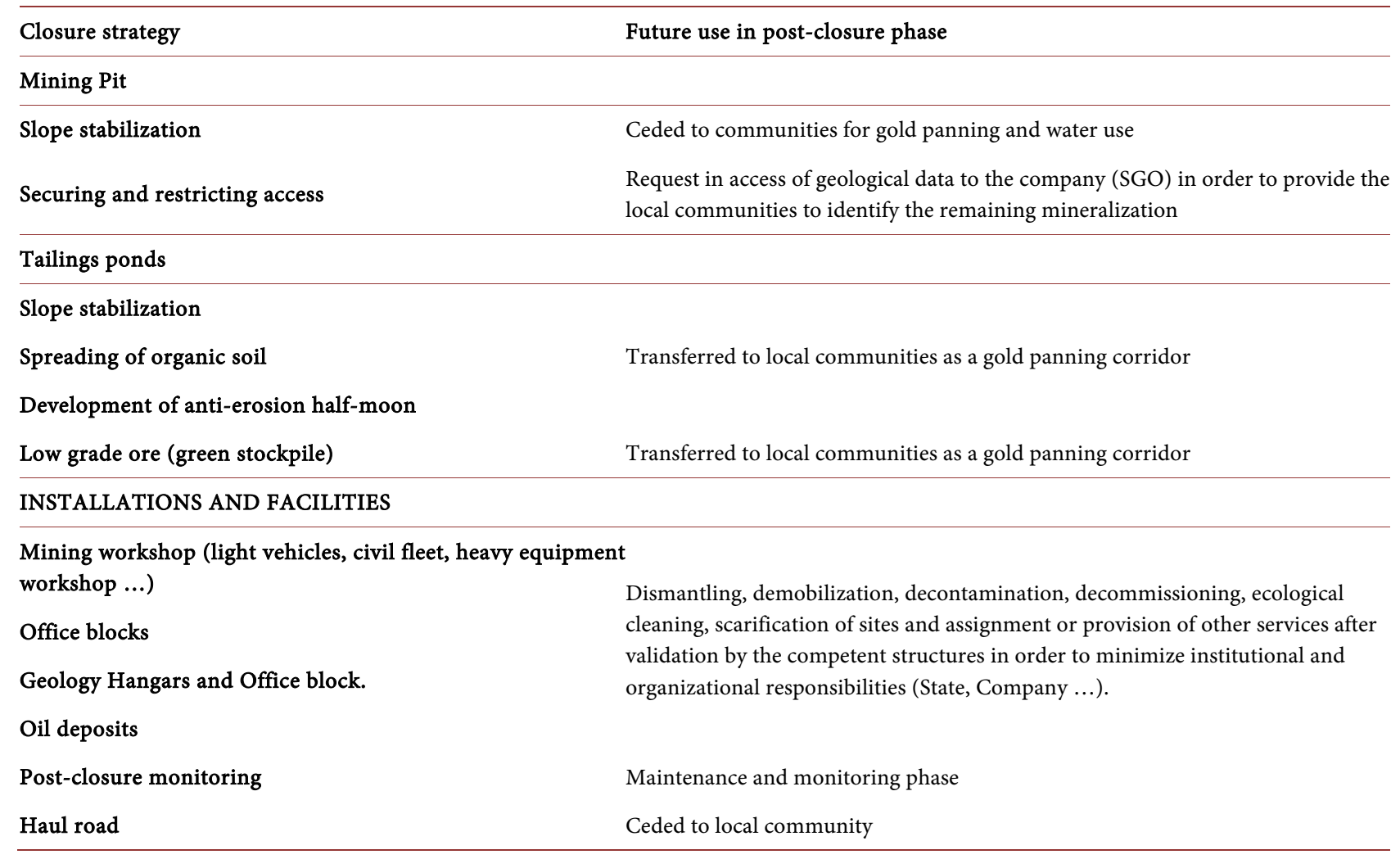

- Blocking infiltration into the disposal area with a waterproof cover;

- Remodeling the land to restore the natural configuration and vegetation of the surface;

- In order to limit the residual impacts of the pollution and reduce the future management costs of the site;

- Monitoring of the site: installation of measuring stations;

- Implementation of a Difpolmine project which includes two components;

- Groundwater control;

- Implementation of a phytostabilization protocol promoting revegetation to regain the appearance of a natural environment taking into account the land characteristics (local species resistant to the presence of arsenic in the soil, soil amendment using species rich in iron which inhibits arsenic, crushing of the soil over $15 \mathrm{~cm}$, seeding).

These studies show the complexity of the rehabilitation of large polluted areas. This is an innovative project, as it involves large-scale phytostabilisation. The monitoring of soil quality and the plants will make it possible to evaluate the effectiveness of the method in the long term and to check whether the combination of the methods used (demolition, containment, water management, vegetation) proves to be a relevant solution applicable to other sites.

\section{Lessons learned in the rehabilitation of the Sabodala gold mine project}

The recovery of mining residues is increasingly becoming one of the greatest challenges for sustainable development in the mining sector [40] [41] [42] [43] 
[44]; poor tailings management compromised the sustainability of environmental and social management measures implemented during the life cycle of most closed mines.

This is why the company Sabodala Gold Operation understood very well the importance of mining residues, especially those from the Tailling storage facility TSF; the feasibility of recovering mining residues has been proven by field studies by [31]. In the case of the closure of Gora owned by the company Sabodala Gold Operation, our approach of consulting all stakeholders directly or indirectly associated with the mining activity of Gora has yielded excellent results. People understand the importance of sustainable tailings management in the context of Sustainable development. Several management options have been identified and will be the subject of other scientific publications.

In order to avoid the disasters noted in large mines such as Salsigne presented above and to achieve a closed mine in the perspective of sustainable development, at the end of this intervention, we strongly recommend that:

1) At the institutional level, states should develop guidelines for the rehabilitation of gold mines and especially for the management of the post-mining period in the context of the signing of mining conventions in order to avoid the future birth of dead towns at the end of mining operations; this recommendation can be made operational through collaboration with the world bank which in its press release of May 1, 2019 informs to have created a new fund intended for the financing of a mining operation in support of the energy transition. A pilot program could be set up for this purpose integrating on the one hand a sustainable mining as recommended by the World Bank and, on the other hand by rehabilitation and closure of these mining sites;

2) Include in the preceding negotiations the signing of mining conventions, the transfer of mining components; these facilities could be financially evaluated and integrated into a form of guarantee for mine closure;

3) From a strategic point of view, additional studies should be carried out as part of a program to evaluate the impacts of the rehabilitation and closure of mining sites on sustainable development, corporate social responsibility, the EITI, the legislation of African states, and especially on biodiversity, in order to make the rehabilitation of mining sites evolve towards a restoration of the ecological functions of these sites;

4) Specifically, object of studying the Gora/Sabodala mine closure is related to deal with issues concerning reinforcing the capacities of the local actors and of all the stakeholders who have very little knowledge in rehabilitation plans, industrial mining installations and the closure process of gold mines; it will thus be necessary to sensitize the populations on the inherent risks in the closed mines in order to avoid the accidents;

5) In an operational point of view, the success of the rehabilitation and closure of the Gora/Sabodala gold mine must take into account the rigorous rehabilitation tests carried out by the environmental department of the Sabodala mine and presented in this report, as well as the conclusions of the work of the closure 
monitoring committee;

6) Finally, the States should systematically issue mine closure permits to mining operators who have complied with the legal, regulatory and normative, environmental, safety and social specifications.

Senegal is thus closing its first gold mine, which should be a success, as it is a model for its gold mining industry. The application of these recommendations would prevent numerous problems related to the post-mining phase and all the negative consequences that could result from it.

\section{Conclusions}

The commitment of Sabodala Gold Operations in a responsible rehabilitation and consensual closure of Senegal's first gold mine is an excellent initiative in this Senegalese gold industry for sustainable development. However, much remains to be done with respect to the rehabilitation of gold mines. Indeed, the skepticism regarding successful rehabilitation must encourage operators to be more responsible and to use accessible technology in a transparent manner in order to achieve the expected consensual results. In the case of the Salsigne gold mine in France, despite all the efforts made, the arsenic pollution is such that its remediation is almost impossible. The lack of knowledge in risks associated with a closed gold mine by local actors is a major issue. In fact, the populations have only one main proposal; namely, the closed mines and their various components must be returned to them for exploitation of the gold residues (Low grade ore). The problem of effective treatment of effluents is also a permanent challenge for the mining industry, taking into account the great variability of the contaminants and their concentrations. Through this study, it was noted that in Senegal, there is no consensus among the parties involved in the closure of mining sites and the guarantee of cessation or end of activity, making it almost impossible to carry out the environmental monitoring that would help to limit the risks of pollution and post-closure accidents. Other external factors such as changes in the price of precious metals, particularly gold, make it extremely difficult to stabilize rehabilitation and closure options (Table 1) over the long term because of the many procedurals and functional changes made by project managers to keep their mines alive.

Despite the many concerns and shortcomings in mine rehabilitation and closure worldwide, the rehabilitation of the GORA/SABODALA gold mine, the first to be closed in Senegal, may well be successful if it takes into account the social (social acceptability of future site functions), ecological (restoration of the site's ecological functions), and cultural (preservation of local cultural heritage) dimensions. This study has shown a very strong dependence of the populations towards the mine. To illustrate this, when the village of SABODALA was relocated, the populations chose a new site that was much closer to the mine to avoid losing the supposed profits generated directly by the mining company on the one hand, and on the other hand to be able to recover the site at the end of 
gold mining without taking into account the end of the mine's life and all the consequences that would follow. However, the financial aspect remains the major constraint in rehabilitation success; as such, it is necessary that in the current design of gold mining projects that the basic costs of technical studies include the rehabilitation costs and closure activities. In order this measure becomes effective, the very costly and restrictive idea of "close and rehabilitate" must be abandoned for good in favor of progressive rehabilitation, which can only be successful if mining engineering or planning of mining operations integrates rehabilitation activities upstream and at all phases of a project. This may include the integration of progressive rehabilitation modules and sustainable management of taillings into the curricula of mining schools.

\section{Acknowledgements}

We would like to thank the private mining industry in particular Mr. Abdou Aziz SY and Mr. David Mbaye Managing Director of the Sabodala gold operation and the Barrick Gold Senegal for their leadership in Senegal's mining sector. We also thank the universities of Amadou makhtar Mbow and the African Institute of Management as well as the actors of the public sector who made this mission successful.

\section{Conflicts of Interest}

The authors declare no conflicts of interest regarding the publication of this paper.

\section{References}

[1] Goffé, B. (2013) Matière et énergie: Stocks et cycles. Dans L'énergie à découvert sous la direction de R. Mosseri et C. Jeandel. CNRS Éditions, 352. http://bip.cnrs-mrs.fr/bip06/pdf/130215 Energie Synopsis.pdf

[2] Hakkou, R., Benzaazoua, M. and Bussière, B. (2008) Acid Mine Drainage at the Abandoned Kettara Mine (Morocco): 2. Mine Waste Geochemical Behavior. Mine Water and the Environment, 27, 160-170. https://doi.org/10.1007/s10230-008-0035-7

[3] Griffith, J.J., Dias, L.E. and Jucksch, I. (1996) Rehabilitation of Mine Sites in Brazil Using Native Vegetation. In: Majumdar, D.S.K., Miller, E.W. and Brenner, F.J., Eds., Forests-A Global Perspective, Pennsylvania Academy of Science, Easton, 470-488.

[4] Ricks, G., et al. (1999) Les aspects environnementaux de la programmation de la fermeture des mines. Programme des Nations-Unies pour l'environnement. Cardiff, Grande-Bretagne.

[5] Bouyoud, F. (2007) The Institutionalization of Corporate Social Responsibility: Theoretical Principles. Communication at the 5th ADERSE Congress, Grenoble, 10-11 January 2007, 8 p.

https://www.aderse.org/docatelecharger/congres aderse 2008/actes/Articles/Sessio n\%201.1/Linstitutionnalisation\%20de\%20la\%20Responsabilite\%20Social.pdf

[6] Chair in Eco-Consulting (2012) Social Acceptability of Mining Projects: The Contribution of Participatory Processes. University of Quebec at Chicoutimi, Saguenay. 
[7] International Council on Mining and Metals (2010) Guide to Good Practice: Indigenous Peoples and Mining. ICMM, London.

https://www.icmm.com/website/publications/pdfs/social-performance/2015/guidan ce indigenous-peoples-mining.pdf

[8] Huybens, N., Segers, I., Dessureault, P.-I. and Villeneuve, C. (2012) Social Acceptability of Mining Projects: The Contribution of Participatory Processes. University of Quebec at Chicoutimi, Chair of Research and Intervention in Eco-Consulting, Saguenay. http://ecoconseil.uqac.ca/rapports-dintervention

[9] Pegg, S. (2003) Poverty Reduction or Poverty Exacerbation? World Bank Group Support for Extractive Industries in Africa. Department of Political Science, Indiana University Purdue University Indianapolis (IUPUI), Indianapolis.

http://oxfam-us.s3.amazonaws.com/www/static/oa3/files/poverty-reduction-or-pov erty-exacerbation.pdf

[10] The Pembina Institute (2008) Boom to Bust: Social and Cultural Impacts of the Mining Cycle. The Pembina Institute, Calgary. https://constellation.uqac.ca/5260/

[11] Environmental Protection Authority (2006) Annual Report. 70 p.

[12] Society for Ecological Restoration Australasia (2021) National Standards for the Practice of Ecological Restoration in Australia Standards Reference Group, Society for Ecological Restoration Australasia in Consultation with Key Partners. Edition 2.2. https://www.seraustralasia.org

[13] Ruiz-Jean, M.C. and Aide, M. (2005) Restoration Success: How Is It Being Measured? Restoration Ecology, 13, 569-577.

https://doi.org/10.1111/j.1526-100X.2005.00072.x

[14] Bussière, B., Aubertin, M., Zagury, G.J., Potvin, R. and Benzaazoua, M. (2005) Main Challenges and Possible Solutions: Mineral Resources and the Development of Africa for the Restoration of Storage of Abandoned Mine Tailings. 2005 Symposium on the Environment and Mines, Rouyn-Noranda, 15-18 May 2005, 68 p.

[15] Economic Commission for Africa and African Union (2011) Mineral Resources and Africa's Development: Report of the International Study Group on Africa's Mineral Regimes. ECA Publications and Conference Management Section, Addis Ababa. https://repository.uneca.org/bitstream/handle/10855/21569/Bib-69220.pdf?sequenc $\underline{\mathrm{e}=1 \text { \&isAllowed }=\mathrm{y}}$

[16] Hakkou, R., Benzaazoua, M. and Bussière, B. (2008) Acid Mine Drainage at the Abandoned Kettaramine (Morocco): 1 Environmental Characterization. Mine Water and the Environment, 27, 145-159.

https://doi.org/10.1007/s10230-008-0036-6

[17] Diéye, P. (2010) Reconstitution d'un paysage minier, cas de la mine de phosphate de Taïba (Sénégal) Mémoire de Masters en Écologie, laboratoire d'écohydrologie de l'université cheikh Anta Diop de Dakar (35 pages).

[18] International Finance Corporation (World Bank Group) (2012) Sustainable and Responsible Mining in Africa. Report, $57 \mathrm{p}$.

https://www.ifc.org/wps/wcm/connect/14d1fb8c-8d63-47c9-acb7-35b20a488ff2/Sus tainable+Mining+in+Africa.pdf?MOD=AJPERES\&CVID $=\mathrm{knWL6Rr}$

[19] Diéye, P. (2018) La gestion environnementale dans le secteur minier au SÉNÉGAL. Direction de l'environnement and des établissements classés. Communication. Salon International des mines Hôtel King Fahd palace, novembre 2018.

[20] Buxton, A. (2012) MMSD + 10: Reflecting on a Decade of Mining and Sustainable Development. International Institute for Environment and Development, London. http://pubs.iied.org/pdfs/16041IIED.pdf 
[21] World Commission on Environment and Development (1988) Our Common Future. Les Éditions du Fleuve, Montreal.

[22] Ferrand, D. (2000) Managing the Environment in the Company. Ordre des ingénieurs du Québec, Montreal.

[23] National Initiative for Orphaned or Abandoned Mines (2013) Annual Report 2013. Mining Association of Canada (MAC), Ottawa. https://mining.ca/wp-content/uploads/2019/03/AnnualReport2013.pdf

[24] Kerr, R. (2010) Stakeholders' Views of Mining and Sustainable Development. GlobeScan, Toronto, 2393.

https:/globescan.com/wpcontent/uploads/2017/07/Stakeholders Views of Mining and Sustainable Development Full Report GlobeScan ICMM.pdf

[25] United Nations (2015) The General Assembly Adopts an Ambitious Sustainable Development Program to "Transform Our World" within 15 Years. http://www.un.org/press/fr/2015/ag11688.doc.htm

[26] Corporate Network and Sustainable Development (2012) Innovating for Sustainable Development: A Guide for Executives. REDD, Montreal. https://redd.nbs.net/s/Rapport executif_Innovation.pdf

[27] Segers, I. (2014) Dialogue, Ethics and Sustainable Development for the Practice of Eco-Counseling. Master's Thesis, University of Quebec at Chicoutimi, Saguenay. https://constellation.uqac.ca/2797/1/030623016.pdf

[28] Tremblay, D., Bensalah, N., Côté, H. and Villeneuve, C. (2013) Report of the Sustainable Development Analysis Process of the Arnaud Mining Project According to the Analysis Grid of the Chair in Eco-Consulting. University of Quebec at Chicoutimi, Chair of Research and Intervention in Eco-Consulting, Saguenay.

https://www.google.com/url?sa=t\&source=web\&rct=j\&url=http://ecoconseil.uqac.c a/wpcontent/uploads/2015/06/Rapport analyse DD Mine Arnaud VF.pdf\&ved=2 ahU-

KEwjd3OiGw9fzAhXNxIUKHdyCCkQFnoECAoQAQ\&usg=AOvVaw1ItGV8gS81s IfEP9VBCHFk

[29] United Nations Environment Program (2013) Metal Recycling: Opportunities, Limits, Infrastructure. A Report of the Working Group on the Global Metal Flows to the International Source Panel.

[30] World Aluminum Institute (2015) Aluminum for Future Generations. http://recycling.world-aluminium.org/review/industry-structure.html

[31] Dia, I., Diagne, M., Gueye, M., Barnes, A. and Mace, C. (2020) Geomochemical Comparison of Fresh and Weathered Tailings from the Sabodala Gold Mine Kedougou Region, Senegal après six ans d'exploitation. Journal of Geoscience and Environment Protection, 8, 177-194. https://doi.org/10.4236/gep.2020.87010

[32] Hpr Ankh, Channel Research (2014) Évaluation de l'impact environnemental and social de l'extension d'une mine: Cas du projet de Gora/Sabodala gold operation.

[33] Dfat (2016) Réhabilitation de sites miniers programme des bonnes pratiques pour le développement durable de l'industrie minièreaoût 2016.

https://www.industry.gov.au/sites/default/files/2019-04/lpsdp-mine-rehabilitation-h andbook-french.pdf

[34] Arnaud, F., Serralongue, J., Winiarski, T. and Desmet, M. (2010) An Ancient Metal Pollution in the Upper Arve Valley. ArcheoSciences Journal of Archeometry, No. 34, 197-201. https://doi.org/10.4000/archeosciences.2759

[35] Borrel, E.L. (1883) Historical Note on the Mines of Savoy. Collection of Memoirs 
and Documents from the Academy of the Isère Valley, Series I (4): 297-364.

[36] Davis, R.A., Welty, A.T., Borrego, J., Morales, J.A., Pendon, J.G. and Ryan, J.G. (2000) Rio Tinto Estuary (Spain): 5,000 Years of Pollution. Environmental Geology, 39, 1107-1116. https://doi.org/10.1007/s002549900096

[37] Dudka, S. and Adriano, D.-C. (1997) Environmental Impacts of Metal Ore Mining and Processing: A Review. Journal of Environmental Quality, 26, 590-602. https://doi.org/10.2134/jeq1997.00472425002600030003x

[38] El Amari, K., Valera, P., Hibti, M., Pretti, S., Marcello, A. and Essarraj, S. (2014) Impact of Mine Tailings on Surrounding Soils and Ground Water: Case of Kettara Old Mine, Morocco. https://doi.org/10.1016/j.jafrearsci.2014.07.017

[39] Diémé, P.C. (2016) Essai de réhabilitation de sites miniers à ciel ouvert: Analyse comparative entre la revégétalisation and la régénération naturelle des zones tests des haldes à stériles de la mine d'or de SABODALA (Sénégal).

[40] Argane, R., Benzaazoua, M., Bouamrane, A. and Hakkou, R. (2014) Upgrading of Mining Waste from the $\mathrm{Pb}-\mathrm{Zn}$ District of Touissit-Boubker (Eastern Region-Morocco). Waste Science \& Technology, 66, 38-44.

https://hal.archives-ouvertes.fr/hal-03170639/document

[41] Bossé, B., Bussière, B., Hakkou, R., Maqsoud, A. and Benzaazoua, M. (2013) Assessment of Phosphate Limestone Wastes as a Component of a Store-and-Release Cover in a Semiarid Climate. Mine Water and the Environment, 32, 152-167. https://doi.org/10.1007/s10230-013-0225-9

[42] Hakkou, R., Benzaazoua, M. and Bussière, B. (2016) Valorization of Phosphate Waste Rocks and Sludge from the Moroccan Phosphate Mines: Challenges and Perspectives. Procedia Engineering, 138, 110-118. https://doi.org/10.1016/j.proeng.2016.02.068

[43] Taha, Y., Adnani, M., Hakkou, R. and Mansori, M. (2014) Upgrading of the Scale Discharge from the Hajjar Hydrometallurgical Plant in Clay Brick. International Conference Regulating the Case of Mine Wastes through Best Management Practices, Marrakech, 5-7 May 2014, 231 p.

[44] Taha, Y., Benzaazoua, M., Hakkou, R. and Mansori, M. (2016) Natural Clay Substitution by Calamine Processing Wastes to Manufacture Fired Bricks. Journal of Cleaner Production, 135, 847-858. https://doi.org/10.1016/j.jclepro.2016.06.200 